[To be published in The Law and Practice of International Courts and Tribunals 2019/2020]

\title{
Let us Not Forget about the Role of Domestic Courts in Settling Investor-State Disputes
}

\author{
Szilárd Gáspár-Szilágyi*
}

\begin{abstract}
This overview illustrates that there is a gap in our knowledge of how domestic courts handle investorstate disputes. As it turns out, some foreign investors use the domestic courts of the host State prior to initiating investment treaty arbitration. Subject matter-wise these cases are very diverse, and not all of them are initiated by investors against the host State. Moreover, in the four countries analysed, investors often appealed to the highest courts of the land, but they lost more cases than they won. These findings should help UNCITRAL Working Group III conceptualize the meaning of 'investor-state dispute' and the relationship between domestic and international methods of ISDS. It concludes by inviting further empirical research to understand how domestic courts handle investor-state disputes. This in turn can help us develop normative arguments as to why domestic courts should be included in the reform process.
\end{abstract}




\section{Contents}

1 Introduction

2 A Significant Part of Investors Relied on Domestic Courts Even if they had the Option to Pursue ITA

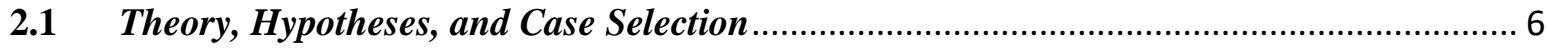

2.2 References to Prior Domestic Court Proceedings ............................................................ 8

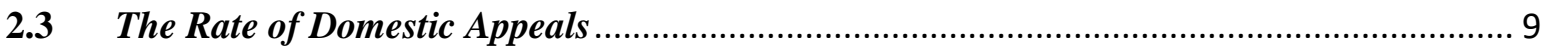

2.4 Domestic Cases Ratione Personae and Materiae .............................................................. 10

2.5 The Success Rate of Investors in the Selected Domestic Cases........................................ 12

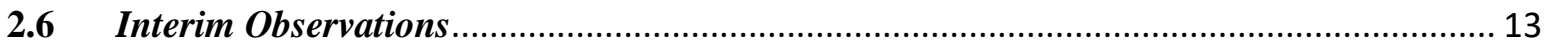

3 Possible Reasons why Investors Rely on the Domestic Courts of the Host State.................. 14

3.1 Why Would Investors Rely on the Domestic Courts of the Host State? ............................... 14

3.2 Why Would Investors Not Rely on the Domestic Courts of the Host State?...................... 16

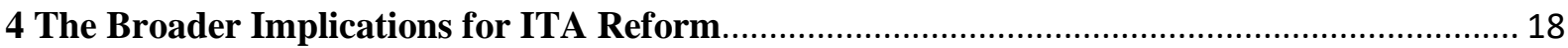

4.1 Thinking about the Roles of Domestic and International ISDS ........................................ 18

4.2 We Need More Empirical Evidence on the Role of Domestic Courts ................................ 20

4.3 Should Domestic Courts be Co-Opted as Investment Courts? .......................................... 21

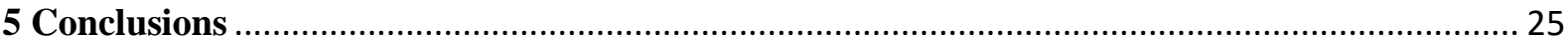




\section{Introduction}

The United Nations Commission on International Trade Law (UNCITRAL) Working Group III is considering multiple avenues through which investor-state dispute settlement (ISDS) could be reformed. These include: (a) setting up a standing, Multilateral Investment Court; (b) the creation of an Appellate Body; (c) keeping the status quo; or (d) resorting to domestic courts. ${ }^{1}$

Working Group III has split the concerns surrounding investment treaty arbitration (ITA) into four main groups: consistency and related matters, ensuring the independence and impartiality of arbitrators, the appointment of arbitrators, and the cost and duration of proceedings. Working Group III also highlighted the need to reduce the duration and cost of proceedings by using forms of dispute settlement 'other than arbitration', such as negotiation, consultations, diplomatic efforts or mediation. ${ }^{2}$ Furthermore, they acknowledge the need to use ITA as a 'last resort recourse'. ${ }^{3}$

It is important, however, not to lose sight of the broader aim of the UNCITRAL reform process, which is to identify possible concerns relating to ISDS and to develop relevant solutions to such concerns. ${ }^{4}$ Investor-state dispute settlement is not restricted to investment treaty arbitration. As Behn's 2017 study notes, 'the majority of [ITA cases] appear to be claims of last resort' ${ }^{5}$ and ITA seems to form the tip of the iceberg. Thus, if one were to liken ISDS to an iceberg, ITA would be the most visible part of it. Yet, ISDS also includes various international alternative dispute resolution mechanisms (mediation, negotiation, and conciliation), commercial arbitration, domestic administrative proceedings, and domestic court proceedings in the host State. Some of these ISDS methods are less visible than ITA and remain under-studied. Therefore, in our effort to provide some ailments to the problems of ITA, we

\footnotetext{
*Former Postdoctoral Fellow, PluriCourts, University of Oslo [szilard.gaspar-szilagyi@ jus.uio.no]. This work was partly supported by the Research Council of Norway through its Centres of Excellence funding scheme, project number 223274. I would like to thank Prof Ole Kristian Fauchald, Prof August Reinisch, Dr Daniel Behn, Maxim Usynin, Dr Silje Hermansen and the participants of the 'Reforming International Investment Arbitration' conference hosted by the ISDS Academic Forum, PluriCourts/LEGINVEST, and CIDS (February 2019).

1 For the updated workings of UNCITRAL Working Group III see <http://www.uncitral.org/uncitral/en/ commission/working_groups/3Investor_State.html> accessed 23 July 2019.

2 UNCITRAL WGIII, "Report of Working Group III on the work of its thirty-fourth session", A/CN.9/930/Rev1, 25 June - 13 July 2018 <https://undocs.org/A/CN.9/930/Rev.1 > accessed 23 July 2019, at 8/13, para. 52.

${ }^{3}$ UNCITRAL WGIII, "Possible Reform of ISDS - Cost and Duration", A/CN.9/EG.III/WP.153, $36^{\text {th }}$ Session, 29 Oct - 2 Nov $2018<$ https://documents-dds-ny.un.org/doc/UNDOC/LTD/V18/057/51/PDF/V1805751.pdf?Open Element $>$ accessed 23 July 2019, at 2/22.

${ }^{4}$ UNCITRAL WGIII, "Possible Reform of Investor-State Dispute Settlement (ISDS)", A/CN.9/WG.III/WP.149, 5 September 2018 < http://www.uncitral.org/uncitral/en/commission/working_groups/3Investor_State.html> accessed 23 July 2019, at 5/15.

${ }^{5}$ Daniel Behn, "Performance of Investment Treaty Arbitration", in T. Squatrito et. al. (eds.), The Performance of International Courts and Tribunals (OUP, 2018) 89, 94-95.
} 
risk not considering the less visible parts of the 'ISDS iceberg', such as domestic court proceedings.

The reform process is predicated on the importance of 'a factual underpinning of its deliberations' and the reliance on empirical and statistical evidence. ${ }^{6}$ Whilst recent empirical projects $^{7}$ have provided us with a lot clearer image of ITA, I have yet to find any empirical studies that take a critical look at domestic court proceedings between investors and the host State. Therefore, I argue that before we move forward with any of the four reform options, we first need to have a better understanding of what happens in domestic courts prior to the commencement of investment treaty arbitration (ITA).

Taking a step back from ITA is crucial because one of the major justifications for having ITA in the first place, is to ensure that investor-State disputes are denationalized. Thus - so the argument goes - investors will not be subjected to domestic courts that lack independence, are less efficient, or are biased against foreigners. ${ }^{8}$ However, much of this justification is premised on anecdotal evidence and not actual studies. Recent empirical studies have shown that several justifications for having ITA and international investment agreements (IIA), such as the depoliticization $^{9}$ of the disputes and the promotion of investments ${ }^{10}$ rest on shaky grounds.

In light of the above, in the following overview I will discuss the broader implications for the ISDS reform process of an empirical project I conducted from late 2017 to early 2018. In that study of four countries (USA, Canada, Romania, and Hungary), I looked at the domestic court proceedings that preceded ITA cases ${ }^{11}$ in order to assess whether investors resorted to the

${ }^{6}$ UNCITRAL WGIII, "Possible Reform of ISDS" (supra note 4), at 3/15.

${ }^{7}$ Susan Franck et. al., "International Arbitration: Demographics, Precision and Justice", ICCA Congress Series No. 18, Legitimacy: Myths, Realities, Challenges (2015); Malcolm Langford, Daniel Behn and Runar Lie, "The Revolving Door in International Investment Arbitration”, 20(2) Journal of International Economic Law (2017); Malcolm Langford and Daniel Behn, "Managing Backlash: The Evolving Investment Treaty Arbitrator?”, 29(2) EJIL (2018) 551.

${ }^{8}$ See Gus van Harten, "Five Justifications for Investment Treaties: A Critical Discussion" 2(1) Trade, Law and Development (2010) 1, Section IV.B; Mavluda Sattorova, "Return to the Local Remedies Rule in European BITs? Power (Inequalities), Dispute Settlement, and Change in Investment Treaty Law", 39(2) Legal Issues of Economic Integration (2012) 223, 226-230.

${ }^{9}$ See Geoffrey Gertz et. al., "Legalization, Diplomacy and Development: Do Investment Treaties De-Politicize Investment Disputes?”, 107 World Development (2018) 239; Leon Trakman and Kunal Sharma, “Jumping Back and Forth Between Domestic Courts and ISDS: Mixed Signals from the Asia-Pacific Region" in S. Hindelang and M. Krajewski (eds.), Shifting Paradigms in International Investment Law (OUP, 2018).

${ }^{10}$ See UNCTAD, "The Role of International Investment Agreements in Attracting Foreign Direct Investment to Developing Countries", UNCTAD Series on International Investment Policies for Development (2009); Kevin P. Gallagher, "Do Investment Agreements Attract Investment? Evidence from Latin America" in K.P. Sauvant and L.E. Sachs (eds.) The Effect of Treaties on Foreign Direct Investment: Bilateral Investment Treaties, Double Taxation Treaties, and Investment Flows (OUP, 2009); J.W. Yackee, "Bilateral Investment Treaties, Credible Commitment, and the Rule of (International) Law: Do BITs Promote Foreign Direct Investment?", 42(4) Law \& Society Review (2008) 805; R. Dolzer, 'The Impact of International Investment Treaties on Domestic Administrative Law', 37 NYU Journal of Int'l Law and Politics (2005) 953, 953-54.

${ }^{11}$ Szilárd Gáspár-Szilágyi, "Why Do or Should Foreign Investors Resort to the Courts of the Host Country Prior to Investment Treaty Arbitration?" in O.K. Fauchald, D. Behn, M. Langford (eds.), The Legitimacy of Investment Arbitration. Empirical Perspectives (forthcoming, CUP 2019/2020) <https://www.academia.edu/37336807/ Why_Do_or_Should_Foreign_Investors_Resort_to the Courts_of the Host_Country_Prior_to_Investment_T reaty_Arbitration> accessed 23 July 2019. 
domestic courts of these four countries prior to initiating ITA (Part 2). I found that over twothirds of the ITA cases against the USA, Romania, and Hungary referred to prior domestic cases, even if investors had the chance to pursue ITA. This number fell slightly under one-half in the case of Canada. More so, I concluded that investors frequently appealed the decisions of lower domestic courts and they had access to the highest courts of the relevant country. Furthermore, most domestic cases were initiated by the investors against the host-State, whilst subject-matter wise the domestic disputes ranged from contractual disputes, to patent infringements, allegations of bribery, etc. Lastly, investors lost most of the domestic cases that preceded ITA.

In Part 3 I discuss some of the reasons why investors relied on domestic courts even when they had the possibility to pursue ITA. I conclude that in most cases absolute ignorance towards ITA and relative ignorance over its potential benefits is hard to justify, since the domestic cases were launched on average over a decade after the entry into force of the investment treaties. What seems to matter is that the domestic disputes are a 'different animal' compared to the international ones. Many are not yet 'ripe' to be argued before an arbitral tribunal and the domestic remedies are different from those offered by ITA. It might also be that domestic proceedings simply cost less than ITA. It is also true that in a number of cases investors purposely did not rely on domestic courts. This might be because investors perceive domestic courts as biased against them. The lack of efficiency of domestic courts, however, is hard to justify in the cases analysed as the studied domestic cases on average lasted as long as ITA proceedings.

Prior to concluding, in Part 4 I discuss the broader implications of the study for the ISDS reform process. I first argue that the study prompts us to delve deeper into how we conceptualize ISDS, the role of various adjudicative bodies and what we understand by an investor-state dispute'. The study also highlights the gap in our understanding of what happens in the bottom half of the 'ISDS iceberg' and the difficulty in gathering such data. Thus, further studies with new methods are needed to better understand domestic ISDS, as one cannot justify the existence of a system of international dispute settlement on broad, anecdotal generalizations of domestic courts. Lastly, I do not argue for the abolition of international ISDS mechanisms, as I view the domestic and international ISDS mechanisms as complementary to one another and not as competing mechanisms. Due to the complementary nature of the two mechanisms, I argue that international ISDS should only kick in, when domestic avenues have failed. 


\section{A Significant Part of Investors Relied on Domestic Courts Even if they had the Option to Pursue ITA}

\subsection{Theory, Hypotheses, and Case Selection}

In this short overview, I cannot do proper justice to the methodology, case selection and delimitation used in the original study. For that, I kindly refer the readers to the original study. ${ }^{12}$ For now, it is worth mentioning that the study was centred on three interconnected questions:

- Do investors rely on the domestic courts of the host State prior to commencing ITA?

- If they do, what are some of the reasons explaining why investors rely on domestic courts?

- Should investors rely on the domestic courts of the host State prior to ITA?

The study then introduced several hypotheses that informed the methodology, the country and the case selection. The study used a dataset of 46 ITA cases and 80/46 domestic cases ${ }^{13}$ that were referenced in the ITA cases. For the purpose of the study, Canada and the United States were considered as highly developed judiciaries, with the occasional, highly publicized exceptions, such as Loewen. ${ }^{14}$ Conversely, Hungary and Romania were classified as transitional judiciaries. ${ }^{15}$ They have transitioned from a communist regime to a market economy and joined the EU in 2004 and 2007, respectively. The 2017 EU Justice Scoreboard conducted on EU Member States found that in Hungary and Romania, slightly more than a third of companies had a negative perception of local courts. ${ }^{16}$ Furthermore, Romania is still under the EU Commission's 'Cooperation and Verification Mechanism' (CVM) which is meant to assist the country in the fields of judicial reform, corruption and organised crime. ${ }^{17}$ In the case of Hungary, the 2018 Sarghentini Report of the European Parliament has been highly critical towards the Hungarian Government's tactics to undermine the rule of law and the independence of the judiciary. ${ }^{18}$ Concerning the theory, one of the justifications for having ITA is to ensure

\footnotetext{
12 Ibid.

${ }^{13}$ Depending on whether one counts a domestic case as a separate case at each level of adjudication. This varies depending on the hypothesis being tested.

${ }^{14}$ Loewen $v$ USA, ICSID ARB(AF)/98/3..

15 "For the United Nations, transitional justice is the full range of processes and mechanisms associated with a society's attempt to come to terms with a legacy of large-scale past abuses, in order to ensure accountability, serve justice and achieve reconciliation.", United Nations, 'Guidance Note of the Secretary-General. United Nations Approach to Transitional Justice', March 2010, 3 <https://www.un.org/ruleoflaw/ files/TJ_Guidance_Note_March_2010FINAL.pdf> accessed 23 July 2019.

${ }^{16}$ European Commission, 'The 2017 EU Justice Scoreboard' (2017) < https://ec.europa. eu/info/sites/info/files/justice scoreboard 2017 en.pdf>, at 37-38, accessed 23 July 2019.

${ }^{17}$ European Commission, 'Cooperation and Verification Mechanism for Bulgaria and Romania', <https://ec.europa.eu/info/policies/justice-and-fundamental-rights/effective-justice/rule-law/assistancebulgaria-and-romania-under-cvm/cooperation-and-verification-mechanism-bulgaria-and-romania en>, accessed 23 July 2019.

${ }^{18}$ European Parliament, 'Report on a proposal calling on the Council to determine, pursuant to Article 7(1) of the Treaty on European Union, the existence of a clear risk of a serious breach by Hungary of the values on which
} 
that investor-State disputes are denationalized, so that foreign investors are not subjected to domestic courts that are biased against them. 'Depending on the country involved', local courts might not be independent from the host government, they might be prejudiced towards foreign investors, local courts might not have the expertise to apply complex principles of international law, and often have inefficient procedures in place. ${ }^{19}$ Advocates for ITA also argue that domestic remedies in 'developing and transition states, and even in developed countries, are inadequate because they take much too long [time], [and domestic courts] are biased, are corrupt, or are otherwise unreliable'. ${ }^{20}$ Furthermore, others have argued that domestic courts present other obstacles to investors, such as domestic courts might defer too much to their national administrations, ${ }^{21}$ or that some jurisdictions condition the launching of a case by the payment of a court fee. ${ }^{22}$ Lastly, the presence of 'fork-in-the-road' (FITR) clauses in the investment treaties might prompt investors to circumvent domestic courts because investorstate tribunals can dismiss a case if the investor brought domestic proceedings.

In light of the above, one may expect that:

- (H1) Foreign investors will circumvent the domestic courts of the host State if they have the option to pursue ITA

- (H2) Foreign investors will more likely circumvent domestic courts in host States with transitional judiciaries than in States with highly developed judiciaries

If foreign investors do in fact resort to domestic courts, are they able/willing to pursue multiple levels of adjudication? One could argue that this will depend on the level of trust that foreign investors have in the domestic judicial system, the available domestic judicial avenues/remedies, and how efficiently domestic courts can handle appeals or other forms of recourse. Thus, investors operating in countries with highly developed judiciaries would appeal more often a lower court's decision, because they trust the system and in a more efficient system the likelihood of obtaining a swift settlement of the appeal is higher. Conversely, investors operating in countries with transitional judiciaries would appeal less often, because they do not trust the impartiality or efficiency of the system and they would rather spend the extra time and money on international arbitration. Thus, we may hypothesize that:

- (H3) Investors operating in countries with transitional judiciaries appealed less than those in countries with highly developed judiciaries did.

the Union is founded' (Sarghentini Report), 2017/2131(INL), <http://www.europarl.europa. eu/sides/getDoc.do?type=REPORT\&reference=A8-2018-0250\&language=EN $>$, accessed 23 July 2019.

${ }^{19}$ Salacuse (n 9) 397-398.

${ }^{20}$ Van Harten (n 1).

21 ibid, 661 .

${ }^{22}$ I would like to thank Prof. August Reinisch for bringing this to my attention. For example, in Romania, all legal or natural persons must pay a 'judicial tax' (taxă judiciară de timbru) when initiating a domestic case, the value of which depends on the value of the claim and whether it is quantifiable or not in a monetary way. For example, for a claim with a value above 250.000 lei (approx. 54.000 euros) the claimant must pay 6105 lei (approx. 1300 euros) plus $1 \%$ of the value exceeding 250.000 lei. See OUG 80/2013 privind taxele judiciare de timbre, Art. 3 complementing Art. 197 of the Code of Civil Procedure. 
What about how investors might perceive domestic courts? It is argued that a low success-rate before domestic courts might create the perception among investors that domestic courts are biased against them. This can happen at two different stages. Firstly, if counsel has information that foreign investors lose more domestic cases than they win, this might inform the investor not to rely on domestic courts but pursue ITA, where the chances of bias might be lower. Secondly, a foreign investor might perceive domestic courts as being biased against it in an individual case, if it loses all/most cases before the local courts. This in turn might give the investor an extra reason to commence international arbitration. Furthermore, if the argument were correct that less developed judiciaries will disfavour foreign investors, then one would expect a higher investor loss rate in transitional judiciaries as opposed to highly developed judiciaries. Therefore, the expectation is that:

- (H4) Foreign investors will have a lower success-rate in domestic courts of the host State prior to ITA and this will be more pronounced in transitional judiciaries

In order to provide a more thorough overview, I also looked at the domestic disputes from the perspective of the disputing parties (ratione personae) and their subject matter (ratione materiae).

The more direct avenue to assess whether foreign investors would circumvent the domestic courts of the host State when they had the option to pursue ITA (H1), was to verify whether the ITA cases against the USA, Canada, Romania, and Hungary (Step 1) referenced prior domestic cases between the investor and the relevant host State (Step 2). Once I identified the references to domestic cases in the international documents, I proceeded to gather the domestic cases from domestic databases or by petitioning domestic courts (Step 3). With this extra information, I could test the rest of the hypotheses (H2, H3, and H4) (Step 4). The following sections shortly discuss the results.

\subsection{References to Prior Domestic Court Proceedings}

As Figures 1 and 2 illustrate, the results for $\mathrm{H} 1$ and $\mathrm{H} 2$ are more nuanced than the hypotheses suggested. When counting all ITA cases that referred to any type of domestic cases, then $70 \%$ of the ITA cases against the USA made references to domestic court proceedings that were initiated prior to ITA. This number is $55 \%$ for Canada, $85.7 \%$ for Hungary, $77.8 \%$ for Romania, and $67.4 \%$ overall for the four countries. These numbers change slightly when counting the ITA cases that referred to relevant ${ }^{23}$ domestic cases, to $70 \%$ of ITA cases against the USA, $40 \%$ against Canada, $71 \%$ against Hungary and $66.7 \%$ against Romania referring to prior domestic

\footnotetext{
${ }^{23}$ I discounted those references in ITA cases against Canada that referred to US domestic cases and several references in ITA cases against Romania and Hungary that referred to cases launched by other parties or before the General Court of the European Union.
} 
cases between the investor and the host State.. The average for the four countries is $56.5 \%$. This result weakens $\mathrm{H} 1$, according to which foreign investors will circumvent domestic courts if they have the option to pursue ITA. The data weakens $\mathrm{H} 2$ as well. In the two transitional countries, Romania and Hungary, the percentage of ITA cases preceded by domestic cases was equally high as in the USA and higher than in Canada.

In conclusion, these findings indicate that at least for the countries included in the study, a large percentage of investors resorted to the courts of the host State prior to initiating ITA, regardless of whether the domestic judiciary was highly developed or transitional.

Figure 1. Percentage of ITA cases referring to any type of domestic cases in the Host State

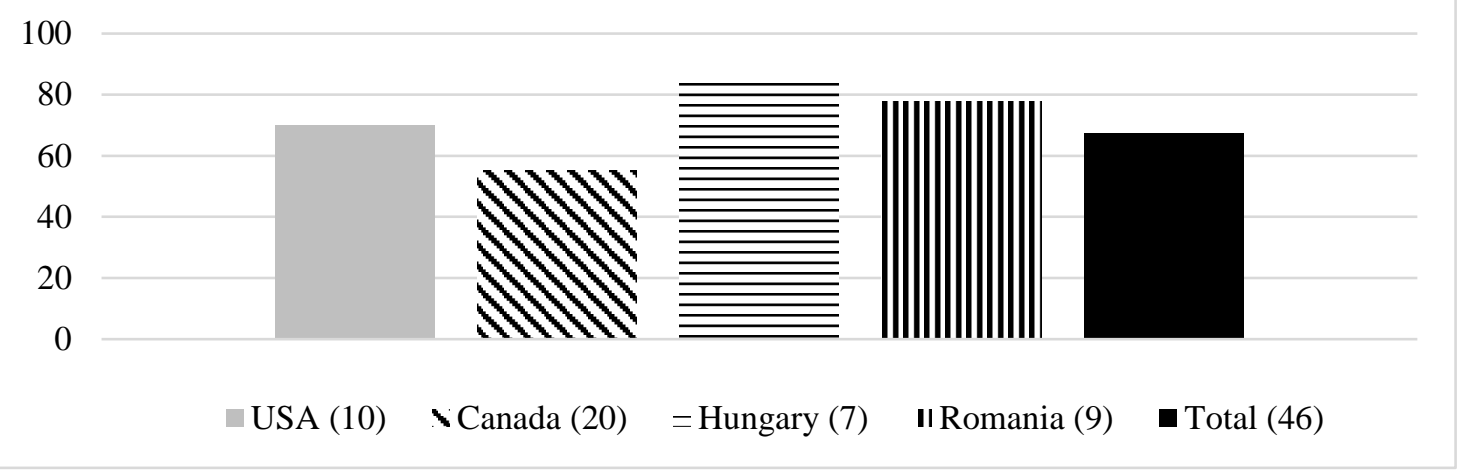

* In brackets the number of ITA cases

Figure 2. Percentage of ITA cases referring to relevant domestic cases in the Host State

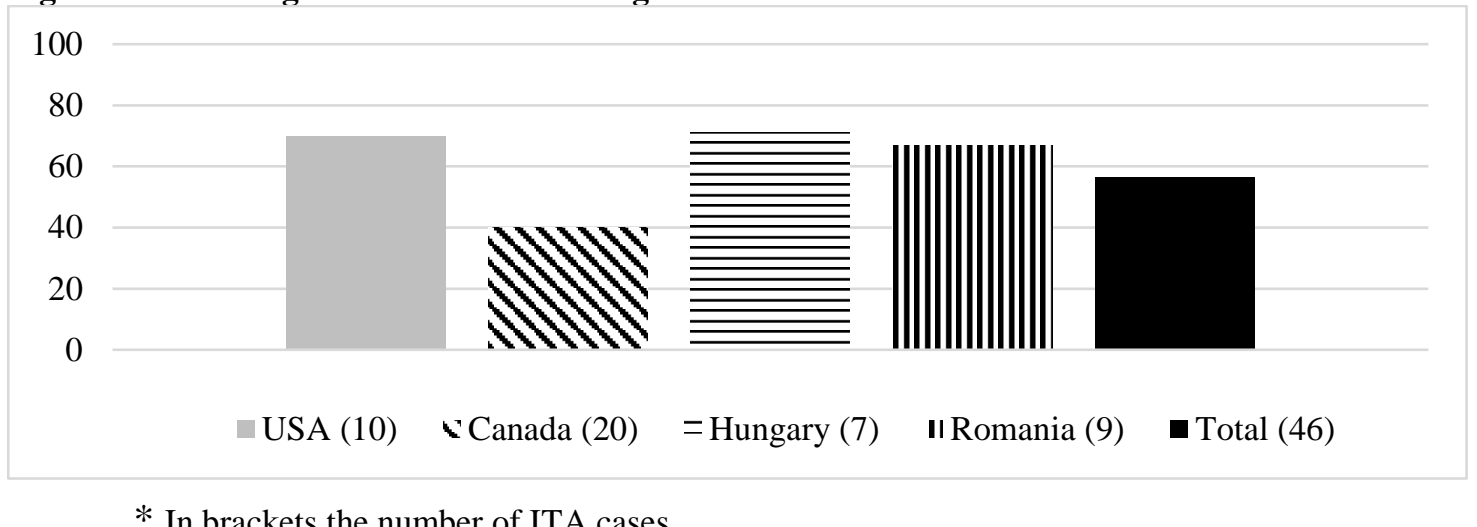

* In brackets the number of ITA cases

\subsection{The Rate of Domestic Appeals}

Next, I looked at the levels of domestic adjudication the investors pursued in order to test the hypothesis (H3) that investors operating in countries with transitional judiciaries appealed less than those in countries with highly developed judiciaries did. As Figure 3 illustrates, in all four countries investors regularly appealed first instance cases that preceded ITA and often ended up before the highest courts of the land. For the USA and Canada the rate of appeal for first instance cases is $40 \%$ and $54 \%$ respectively, while $30 \%$ and $30.8 \%$ of the cases reached the 
highest courts. In the case of Hungary and Romania, the number of appealed first instance cases $(80 \%$ and $82 \%)$ and those that reached the highest courts $(80 \%$ and $64 \%)$ are significantly higher. $^{24}$

Figure 3. Percentage of appealed domestic cases preceding ITA

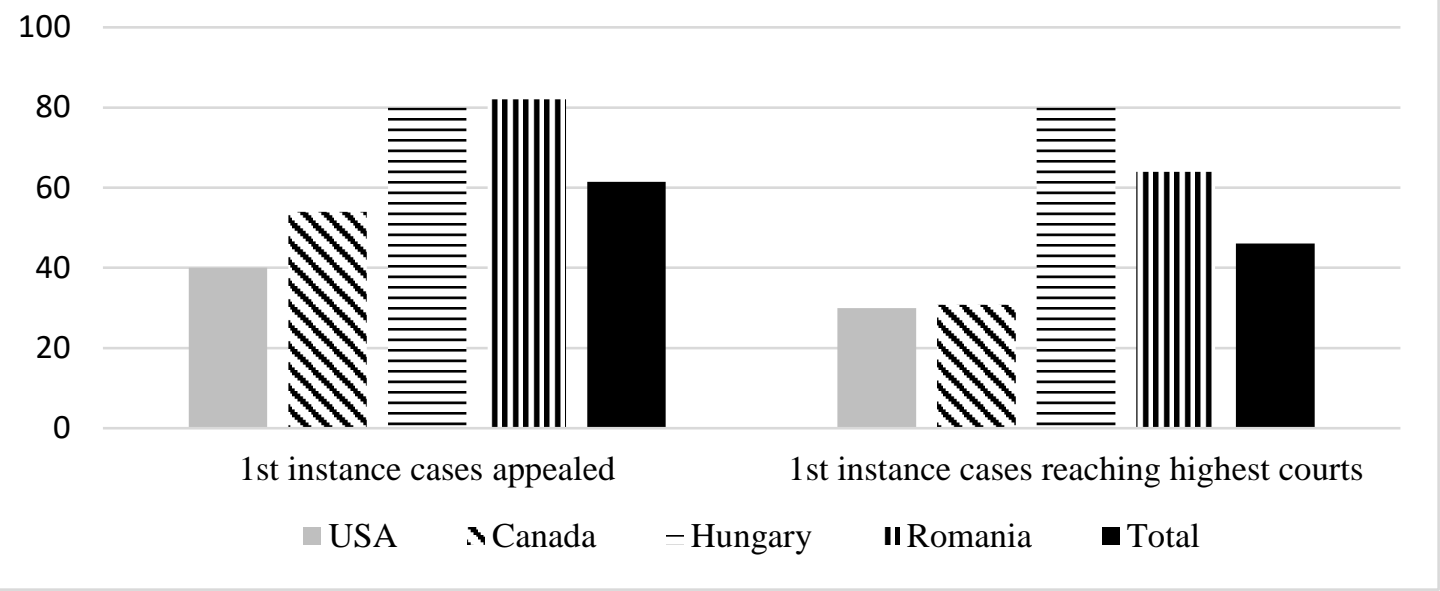

These findings weaken the third hypothesis (H3). Investors in the two transitional judiciaries actually appealed more often than investors in the highly developed judiciaries did, and they reached the highest courts of the land more often. The lower rates of appeals and highest court cases in the USA and Canada might be a result of greater court costs or the difficulty to reach the highest courts in non-unitary states, such as reaching the US Supreme Court. ${ }^{25}$

In conclusion, the data indicates that investors might be willing to pursue multiple levels of domestic adjudication, regardless of whether the judiciary is transitional or highly developed. The possibility to appeal might also influence the decision of investors to resort to domestic courts, since the higher courts can correct possible errors of the lower courts, a possibility not yet present in international investment law. ${ }^{26}$

\subsection{Domestic Cases Ratione Personae and Materiae}

I then looked at the domestic cases ratione personae and materiae. As shown in Figure 4, on average investors initiated most $(83.7 \%)$ of the domestic cases preceding ITA against some form of emanation of the State or State controlled commercial entity. In the case of Canada, it is interesting to note that investors brought $19 \%$ of the cases against other private parties. These are part of the string of cases brought by Eli Lilly against other private competitors for patent

\footnotetext{
${ }^{24}$ In the case of Hungary, the lower number of domestic cases might cause more significant statistical variation.

${ }^{25}$ See United States Courts, 'Supreme Court Procedure' <http://www.uscourts.gov/about-federalcourts/educational-resources/about-educational-outreach/activity-resources/supreme-1> accessed 23 July 2019.

${ }^{26}$ Unless one counts the ICSID annulment proceedings and the Appellate Bodies of the yet to be operational Investment Courts in EU bilateral IIAs.
} 
infringements. Romania is also a curious outlier. Investors initiated only $61.5 \%$ of the domestic cases. Various State bodies initiated the rest of the cases against the investors.

Figure 4. The Disputing Parties in Domestic Cases (Percentage)

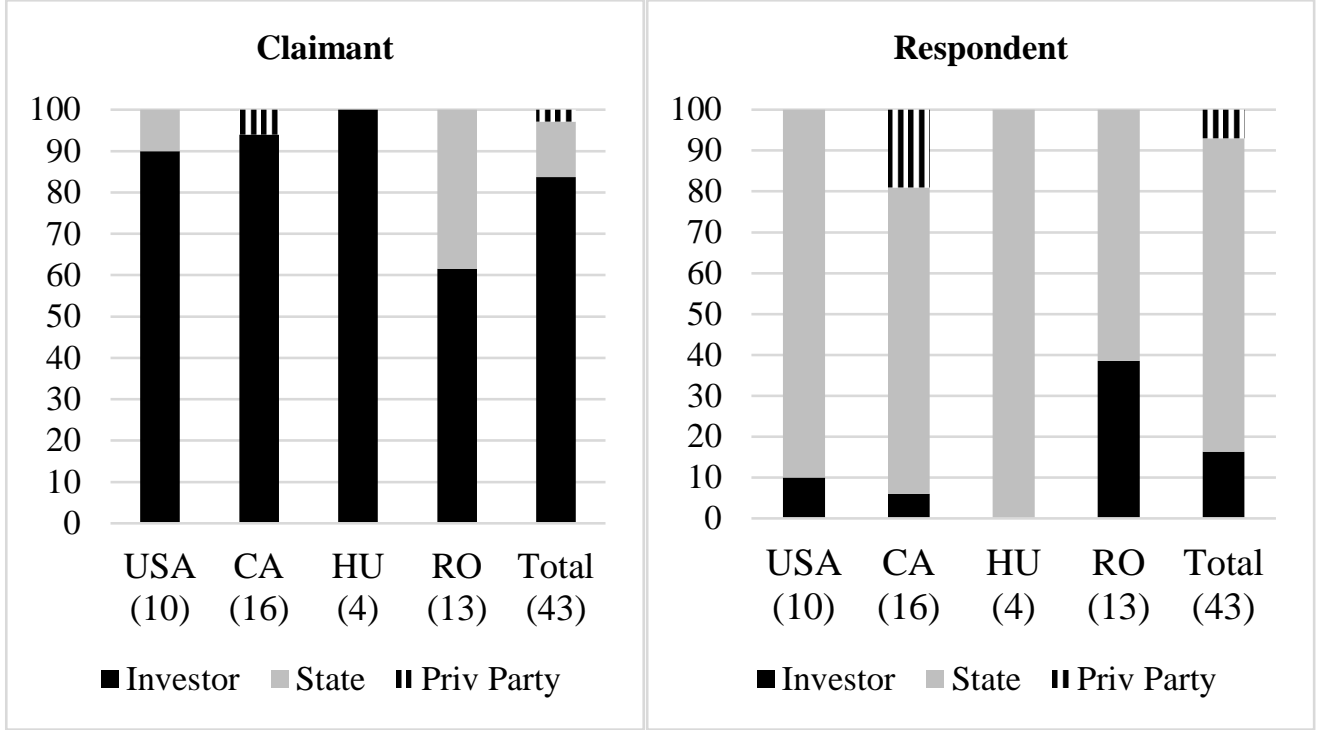

* In brackets the number of domestic cases preceding ITA

Things also get interesting when considering the subject matter of the cases that preceded ITA. Looking at the total number of domestic cases (Figure 5) in the four countries, civil, commercial/economic and judicial/administrative review cases are almost evenly split, followed by intellectual property cases, criminal cases and one case involving international trade matters. The disputes included contractual breaches, patent infringements, challenges to domestic legislation, criminal charges brought against the investor, and even the refunding of cash-deposits from US authorities in an anti-dumping case. ${ }^{27}$ What strikes the eye in the case of Canada - in comparison to the other countries - is the high percentage of cases involving the judicial review of various measures of government institutions/bodies/agencies.

In Romania a number of criminal cases were launched against the investors for alleged bribery, money laundering, etc. For example, the Awdi brothers in Awdi v Romania, ${ }^{28}$ faced criminal charges for money laundering and tax evasion that resulted in lengthy prison sentences. ${ }^{29}$ Conversely, in Rompetrol $v$ Romania ${ }^{30}$ the Dutch incorporated Rompetrol $N V$ had as its main shareholder the late Romanian businessman Dinu Patriciu. In his personal capacity or by representing the Netherlands incorporated company, he won two domestic criminal

\footnotetext{
${ }^{27}$ Tembec Inc v US, US Court of International Trade, 441 F. Supp. 2d 1302.

${ }^{28}$ Awdi v Romania, ICSID ARB/10/13.

${ }^{29}$ See DIICOT v Awdi Hassan \& Awdi Mehdi ('CFR mesagerie'), Bucharest Court of Appeals (Curtea de Apel București), File 49772/3/2012, Decision No. 1489 of 27 Nov 2014.

${ }^{30}$ The Rompetrol Group NV v Romania, ICSID Case No ARB/06/3 (6 May 2013).
} 
cases. ${ }^{31}$ Furthermore, in a set of civil cases that went up to the Supreme Court of Romania, he managed to obtain civil damages from the Romanian Information Services for the secret wiretapping conducted against him. ${ }^{32}$ Interestingly, the local investor in EDF $v$ Romania alleged that it had to bribe Romanian officials in order to get certain concessions at the Bucharest Otopeni International Airport. ${ }^{33}$ The investor did not manage to prove the solicitation of the bribe in a criminal case before the Bucharest Tribunal, later appealed to the Bucharest Court of Appeals. ${ }^{34}$

Figure 5. The Subject Matter of Domestic Cases (Percentage)

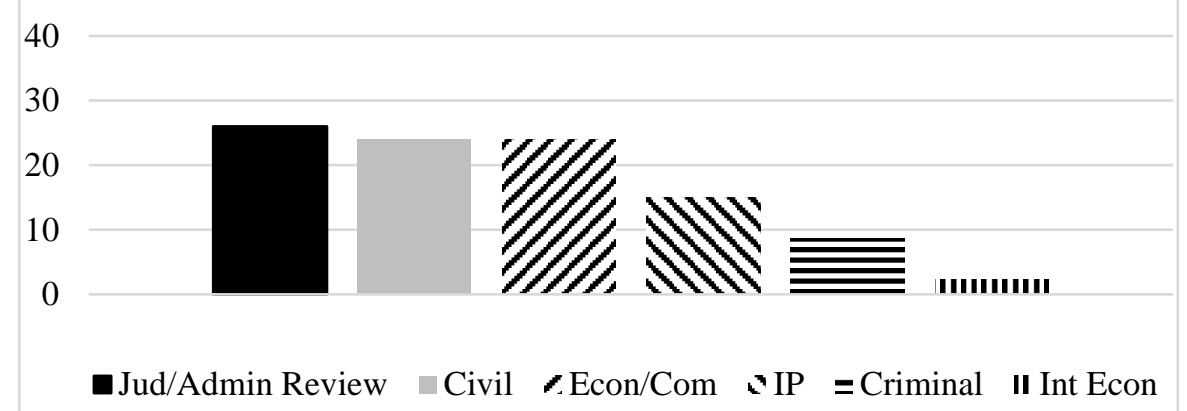

Some important conclusions can be drawn from this data. Firstly, domestic cases that involve foreign investors can cover any type of subject matter and investors actively bring cases against multiple State bodies and their measures, as well as other private parties. This means that States might find themselves on the opposite end of an international arbitral claim, even pursuant to domestic cases that involved only private actors. Secondly, in domestic cases foreign investors can find themselves in the respondent's position as well, either in cases brought by other private parties or by the State. Criminal cases against investors might question our understanding of the bona fide nature of some foreign investors, whilst it might also evidence intimidation tactics by the host State.

\subsection{The Success Rate of Investors in the Selected Domestic Cases}

I also hypothesised (H4) that foreign investors will have a lower success-rate in domestic courts of the host State prior to ITA and that this will be more pronounced in transitional judiciaries. Figure 6 illustrates the investors' success rates at different levels of the domestic proceedings. In all four countries, the rate of investor losses increased as investors resorted to higher domestic

\footnotetext{
${ }^{31}$ See Rompetrol Group NV v PICCJ, Bucharest Tribunal, Criminal Section I, File 12139/3/2006, Decision No. 860 of 29 June 2006; State Prosecutor v D.C. Patriciu, Bucharest Court of Appeals, Criminal Section I, File 10352/3/2006, Decision of 10 April 2006.

${ }^{32}$ S.R.I. v D.C. Patriciu, Romanian Supreme Court, File 12770/3/2006, Decision No 1475 of 18 Feb 2011.

${ }^{33}$ EDF (Services) Ltd v Romania, ICSID Case No ARB/05/13, Award (8 Oct 2009), paras 221-237.

${ }^{34}$ SC EDF ASRO SRL et al v DNA, Bucharest Court of Appeals, Decision 1388 of 27 sept 2007 (File No 390004/3/2006); SC EDF ASRO SRL et al v DNA, Bucharest Tribunal, Criminal Section 2, Decision of 31 May 2007.
} 
courts. Out of a total of 37 first instance cases, investors lost 59.4\%, which increases to $72.3 \%$ if we count only the second and third instance cases. When counting only the third instance cases investor losses increase to $92.3 \%$.

Figure 6. Investor Losses at Different Domestic Levels (Percentage)

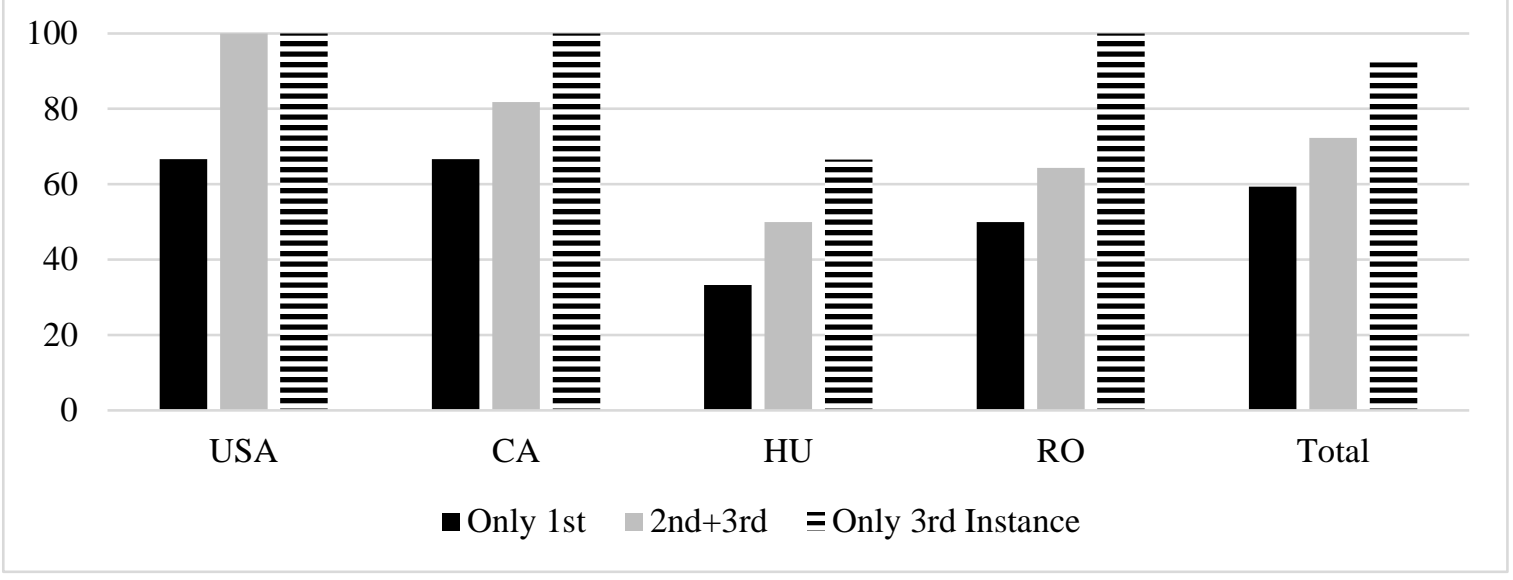

The data partly supports the first part of the hypothesis that foreign investors have a lower success rate in domestic courts of the host State prior to initiating ITA; investors lost more cases in the United States, Canada, and Romania, while in Hungary, investors won slightly more cases than they lost. However, the data does not support the second part of the hypothesis that the lower success rates are more prevalent in the transitional judiciaries. In both Hungary and Romania, investors on average won more cases than in the United States and Canada.

In conclusion, one cannot readily assume that an investors' success rate is determined by the level of development of the domestic judiciary. Furthermore, the fact that these cases preceded ITA and investors lost more cases at the higher levels of adjudication strengthens Behn's conclusion that investors resorts to ITA as a means of last resort, when other avenues have not delivered the expected results.

\subsection{Interim Observations}

The collected data is limited by multiple factors. Firstly, whenever searching for domestic court cases one has to factor in the different local languages and legal systems. Secondly, in order to test H1, I had to look at domestic cases that preceded ITA cases. Therefore, the data is applicable to this narrow dataset and should not be interpreted as applying to all domestic cases between foreign investors and host States. Looking at all domestic cases that involve foreign investors is virtually impossible, as there is a vast number of companies around the world with some level of foreign capital, which would qualify them as foreign investors under ITA law. Furthermore, often it is difficult to identify who is a foreign investor in domestic cases, as investors register companies under different names domestically or they might be smaller shareholders, the names of which are often not mentioned in domestic court proceedings. 
Nevertheless, this type of research clearly illustrates that we have a large gap in understanding the whole spectrum of disputes that occur between investors and host States. As indicated, domestic disputes that later on end up before investment tribunals cover multiple legal fields, and can arise between private parties as well, not just the investor and the host State. It follows that when states conclude IIAs with ITA clauses they cannot account for the multitude of situations that can turn into an international investment dispute.

The data also weakened some of the assumptions based on anecdotes or accepted understandings of why ITA is needed, the most important being that contrary to our expectation, quite a number of investors first relied on domestic courts, even when they had the chance to pursue ITA. It follows that investors also consider domestic courts as a forum where they can solve their disputes with the host State, not just ITA. Part 3 shortly presents some of the possible reasons why some investors chose domestic courts first, instead of opting for ITA.

\section{Possible Reasons why Investors Rely on the Domestic Courts of the Host State}

The study also considered why some investors would first resort to the domestic courts of the host State, while others would not. In the following, I will shortly discuss both situations.

\subsection{Why Would Investors Rely on the Domestic Courts of the Host State?}

Investors could have relied on the domestic courts of the host State, prior to initiating ITA, for several reasons, three of which deserve some extra attention:

- Investors did not know about ITA and its advantages

- Domestic disputes are different from the international ones

- Other considerations, such as financial costs

Behn's empirical study on 878 ITA cases indicates that ITA has gone through a considerable growth trajectory and there might be a learning curve involved. ${ }^{35}$ Thus, one could argue that when investors - in the cases analysed - initiated domestic proceedings, they did not know about ITA or its advantages. This seems to be a plausible explanation, although with several caveats.

Firstly, in the USA and Canada all the ITA cases - with the exception of one - were initiated under NAFTA, which came into force in 1994 and has been a cornerstone agreement that combines both trade and investment under one roof. ${ }^{36}$ Thus, even if the investors or their counsel did not know about NAFTA Chapter 11 arbitration, they should have known!

Secondly, as Behn suggests, there seems to be a learning curve involved for ITA and its advantages. There are two aspects to be considered: absolute ignorance about ITA as a remedy

\footnotetext{
${ }^{35}$ Behn, "Performance of Investment Treaty Arbitration"” (supra note 5).

${ }^{36}$ Filippo Fontanelli and Giuseppe Bianco, "Converging towards NAFTA: An Analysis of FTA Investment Chapters in the European Union and the United States", 50 Stanford Journal of International Law (2014) 211, 219.
} 
(investors did not know about ITA at all) and relative ignorance about the benefits of ITA (investors knew about ITA, but not about its advantages).

Concerning the argument of absolute ignorance about ITA, one could argue that the investor or counsel might not have known about ITA if the domestic dispute occurred shortly after the IIA came into force. However, as indicated in Table 1, in all four countries on average more than a decade (even two) had passed between the entry into force of the IIA and the initiation of domestic proceedings. Thus, investors and their counsel should or could have known about ITA. Relative ignorance about the benefits of ITA implies that investors and counsel knew about ITA, but not about its advantages. Thus, if investors indeed chose domestic courts because they did not know about the advantages of ITA, then in our examples one should see a decrease in domestic cases over time. However, in these four countries I did not find that the number of domestic cases decreased following the rise of ITA after 2000.

Table 1. Absolute ignorance about ITA

\begin{tabular}{c|c|c} 
Country & \multicolumn{2}{|c}{$\begin{array}{c}\text { Number of years after IIA's entry into } \\
\text { force when domestic case filed }\end{array}$} \\
\hline & First instance (year) & All cases (year) \\
\hline USA & 11.12 & 11.27 \\
\hline Canada & 13 & 13.48 \\
\hline Hungary & 20 & 21.5 \\
\hline Romania & 10.28 & 11.05 \\
\hline Average & 12.7 & 13.57
\end{tabular}

A more compelling reason as to why investors opt to use domestic courts has to do with the type of domestic cases, compared to the international ones, and the remedies that investors seek to obtain. As the research indicates, in most cases, the domestic dispute is different from the international one $;{ }^{37}$ it is initiated by different legal entities, under different legal rules, covering a multitude of different areas of the law. This in turn affects the remedies available to the investors and the adjudicatory mechanisms they can use to obtain those remedies. Furthermore, at this stage of the dispute, a domestic case is probably less costly, less time consuming and the 'dispute' as such is not yet 'ripe' to go to international arbitration. Conversely, the international dispute will often entail some form of prolonged, serious or egregious treatment of the investor that could amount to a breach of the international standards of protection contained in the IIA. For example, an expropriation claim under an IIA is not 'ripe' if the host State has provided a mechanism for prompt, adequate and effective compensation, which the investor did not

\footnotetext{
${ }^{37}$ There are exceptions, when the international and the domestic disputes were the same. See George K. Foster, "Striking a Balance Between Investor Protections and National Sovereignty: The Relevance of Local Remedies in Investment Treaty Arbitration", 49 Columbia Journal of Transnational Law (2011) 201, 265, with reference to Pantechniki SA Contractors \& Eng'rs v Albania, ICSID Case No ARB/07/21, Award, TT 67, 105 (July 30, 2009).
} 
invoke. ${ }^{38}$ An investor could also not argue for 'denial of justice' that amounts to a breach of the IIA's fair and equitable treatment standard, if it did not resort to domestic courts. ${ }^{39}$

There are some further considerations for which I could not gather data, but which might also be relevant. Firstly, there might be a financial motive for using domestic courts. International arbitration often requires specialized, highly costly 'boutique' law firms and costly arbitrators in comparison to more resource friendly domestic proceedings. Secondly, ITA can seriously damage the investors' relationship with the host State and is 'often a cause for divorce. ${ }^{40}$ As UNCITRAL WG III mentions:

[...] any dispute between a State and an investor is a burden on both parties. A dispute or even the possibility of a dispute could increase transactional costs of the investors, [...] may entail economic and social costs for States $[\ldots]$ and result in the severance of the link between foreign investors and host States [...]. ${ }^{41}$

Thirdly, investors might want to resort to domestic courts because they can appeal unfavourable decisions, which is currently lacking in ITA, except for the ICSID Annulment Procedure and the appellate bodies of the Investment Courts included into recent EU IIAs, which have yet to fully enter into force As we have seen, in the selected countries investors could and did regularly appeal the decisions of lower courts.

\subsection{Why Would Investors Not Rely on the Domestic Courts of the Host State?}

A number of ITA cases did not refer to prior domestic cases. This might be due to the inconsistent way investment tribunals reference domestic cases, because the investor did not indeed seek domestic remedies and opted for ITA instead, or because some claims cannot be argued before domestic courts. ${ }^{42}$ I looked at three possible explanations:

- Domestic courts are less efficient

- Investors might perceive domestic courts as biased

- The presence of 'fork-in-the-road' clauses

One of the justifications to resort to ITA instead of domestic courts is the latter's lack of efficiency compared to international arbitration, which results in lengthier proceedings. However, not all domestic court systems suffer from protracted and inefficient proceedings. For example, as noted by Bonnitcha et al, in countries such as England \& Wales, France, Germany, Switzerland, and the United States the average length of civil litigation in domestic

\footnotetext{
${ }^{38}$ Ibid., at 248.

${ }^{39} \mathrm{Ibid}$., at 238.

${ }^{40}$ Cédric Dupont and Thomas Schultz, "Do Hard Economic Times Lead to International Legal Disputes? The Case of Investment Arbitration”, 19(4) Swiss Political Science Review (2013) 564, 565.

${ }^{41}$ UNCITRAL WGIII, "Possible Reform of ISDS - Cost and Duration" (supra note 3), at 2/22.

${ }^{42}$ For example, it would be difficult for an investor to argue before a domestic court that the State did not treat it in a 'fair and equitable' manner, if the domestic system does not recognize this standard and/or the domestic system does not allow the investor to invoke the international standard (lack of direct effect or lack of self-executing effect of the IIA).
} 
courts lasted half as much as the average length of ITA disputes. On the other hand, in India the average length to obtain a first-instance decision was nearly double the length of ITA. ${ }^{43}$

As indicated in Table 2, the average length of the selected domestic cases (from first to last instance) was between 4-5 years in Romania, the USA, and Canada, and approx. 2 years in Hungary. This is very similar to the average length of ITA cases of approx. 4 years. ${ }^{44}$ Thus, the inefficiency argument cannot apply to all domestic courts. Furthermore, one should differentiate between the average length of all domestic cases and the average length of domestic cases between foreign investors and host States that precede ITA. In case of the former, investors might be deterred to resort to domestic courts if the average length of domestic court proceedings is excessively long. In the case of the latter, an investor which resorted to the domestic courts first might later resort to ITA in case the individual domestic case is becoming excessively lengthy.

Table 2. Length of domestic proceedings

\begin{tabular}{l|c|c|c}
\multirow{2}{*}{ State } & Only $\mathbf{1}^{\text {st }}$ instance & $\mathbf{1}^{\text {st }}+\begin{array}{c}\mathbf{2}^{\text {nd }}, \text { if } \mathbf{2}^{\text {nd }} \text { is last } \\
\text { instance }\end{array}$ & $\begin{array}{c}\mathbf{1}^{\text {st }}+\mathbf{2}^{\text {nd }}+\mathbf{3}^{\text {rd }}, \text { if } \mathbf{3}^{\text {rd }} \text { is last } \\
\text { instance }\end{array}$ \\
\cline { 2 - 4 } & Average length in months & Average length in months & Average length in months \\
\hline USA & $24.95^{*}$ & 31.5 & 49.75 \\
\hline Canada & 19.8 & 31.2 & 47.3 \\
\hline Hungary & 9.66 & N/A & 22.7 \\
\hline Romania & 14.9 & 14.75 & 58.4
\end{tabular}

* Grand River $v$ King 783 F. Supp. 2d 516 inflates the US average as it lasted for 104.5 months

The data did show, however, that on average investors lost roughly two-thirds of all domestic cases prior to ITA. This has important implications on how investors perceive domestic courts. Counsel might argue that an overall high loss rate for foreign investors in domestic courts is a sign of systemic bias against foreign investors, which could be a reason for not relying on domestic courts. Furthermore, in the individual cases a string of losses or losses before the highest domestic courts can also provide a reason for the investor to pursue ITA.

Lastly, I also looked at the presence of 'fork-in the-road' (FITR) clauses in the IIAs, as a possible impediment to resorting to domestic courts first. FITR clauses require the investor to decide whether it chooses domestic courts or ITA, prohibiting it to have recourse to the other forum once it has made its choice. Thus, if an investor 'wishes to preserve its right to resort to

\footnotetext{
${ }^{43}$ Jonathan Bonnitcha, Lauge N. Skovgaard Poulsen and Michael Waibel, The Political Economy of the Investment Treaty Regime (OUP, 2017)i90-91, Table 3.4.

${ }^{44}$ Anthony Sinclair, "ICSID arbitration: How Long Does it Take?", 4(5) Global Arbitration Review (2009) (115 ICSID cases, 3.63 years); Allen \& Overy, "Investment Treaty Arbitration: Cost, Duration and Size of Claims all Show Steady Increase" (2017) (324 cases, 3.8 years) <http://www.allenovery.com/publications/en$\mathrm{gb} /$ Pages/Investment-Treaty-Arbitration-cost-duration-and-size-of-claims-all-show-steady-increase.aspx ISA $>$ accessed 23 July 2019; Joongi Kim, "Streamlining the ICSID Process: New Statistical Insights and Comparative Lessons from Other Institutions”, 11(1) Transnat'l Dispute Mgmt. (2014) 2 (4.1 years).
} 
international arbitration, it is likely to avoid [domestic] litigation. ${ }^{45}$ However, I did not find any correlation between not bringing a domestic case first and the existence of FITR clauses. To the contrary, three ITA cases against Romania were initiated under IIAs that included a FITR clause ${ }^{46}$ and all three of them referred to prior domestic cases launched by the investor. ${ }^{47}$

With the exception of the Standford Ponzi Scheme cases (discontinued), all the ITA cases against the USA and Canada were initiated under NAFTA. NAFTA does not contain an FITR clause, while its Article 1121 'no-U-turn' clause would not have any discouraging effect on investors bringing prior domestic cases. ${ }^{48}$ In the case of NAFTA it also has to be mentioned that under its statute of limitations clause ${ }^{49}$ investors are barred from bringing a case if more than three years have elapsed from the moment when the investor/investment first acquired/should have acquired knowledge of the alleged breach. However, in the case of the ITA cases against the US and Canada, investors were not barred from initiating arbitration by the statute of limitations clause, even if prior domestic cases existed.

The most likely explanation of why no correlation between the initiation of domestic cases and the presence of the FITR clauses was found is that in practice, FITR clauses do not prevent investors from bringing ITA cases. ${ }^{50}$ In order for this clause to operate properly, one needs an identity of the facts, the disputing parties and the legal rules invoked. In most cases, however, the domestic dispute is brought by a different legal entity than the international one; the facts of the domestic case might differ, as well as the legal rules being invoked.

\section{The Broader Implications for ITA Reform}

The following sections approach the broader implications of the study from three different angles: conceptual, empirical, and normative.

\subsection{Thinking about the Roles of Domestic and International ISDS}

The study invites us to delve deeper into how we conceptualize ISDS, the role of various adjudicative bodies and what we understand by an 'investor-state dispute'.

\footnotetext{
${ }^{45}$ UNCTAD, "Investor-State Dispute Settlement", UNCTAD Series on Issues in International Investment Agreements III (2014) <https://unctad.org/en/PublicationsLibrary/diaeia2013d2_en.pdf> accessed 23 July 2019, at 87.

${ }^{46}$ Awdi v Romania, ICSID Case No ARB/10/13 (United States-Romania BIT, Article VI.3); Noble Ventures v Romania, ICSID Case No ARB/01/11 (United States-Romania BIT, Article VI.3); Rompetrol v Romania, ICSID Case No ARB/06/3 (Romania-Netherlands BIT, Article 8.3).

${ }^{47}$ In Noble Ventures the tribunal mentions prior national cases without giving more detail, while in the other two cases various domestic cases were initiated by the investors and State bodies.

${ }^{48}$ For the differences between the NAFTA Article 1121 and FITR clauses see Todd Weiler, International Investment Law and Arbitration (Cameron May, 2005)313. See also Foster, Striking a Balance Between Investor Protections and National Sovereignty: The Relevance of Local Remedies in Investment Treaty Arbitration, 49(2) Colum. J. Transnat'l L. (2010-2011) 201, 249.

${ }^{49}$ NAFTA, Articles 1116(2) and 1117(2).

${ }^{50}$ UNCTAD (supra note 46 ), at 87.
} 
Investment treaty arbitration has received a lot of criticism in the past decade; therefore, it is no wonder that ITA dominates the discussion of the UNCITRAL reform process. However, the study clearly shows that prior to ITA there is a lot happening at the domestic level that we do not fully understand or have data on. These domestic proceedings are also part of the larger concept of ISDS, and lie in the bottom half of the 'ISDS iceberg'. Therefore, we should not neglect the role of domestic ISDS proceedings if we are to properly understand and reform ISDS. Firstly, understanding what happens at the domestic level might prompt us to re-evaluate the rationale behind having ITA in the first place. Is ITA needed because domestic courts are biased, or because investors do not trust domestic courts, or because ITA denationalizes the dispute? Secondly, domestic proceedings can better inform us about how disputes between investors and host States arise, what steps the parties take to settle the disputes, and the remedies that are available to foreign investors. Thirdly, as further explained in Part 4.3, understanding how domestic disputes unfold is crucial for the discussion whether investors should first exhaust domestic remedies prior to initiating ITA.

Furthermore, the study shows that unlike ITA, which investors initiate under similarly worded IIAs that cover a set of substantive standards, domestic proceedings are a lot more varied ratione personae and materiae. Domestic disputes occur at all levels of adjudication in the domestic systems, they involve a multitude of substantive areas, and investors do not always initiate domestic proceedings. Sometimes the host State commences proceedings against the investor, whilst in other cases disputes between private parties end up forming the basis for the international claim. This should make us think whether the reform process should consider the possibility for States to bring claims against investors at the international level or whether this should be the exclusive prerogative of the investors.

It also makes us question how we define a 'dispute' between an investor and the host State. Analysing domestic cases allows us to understand how investor-state disputes are not static, but evolve. By the time the dispute reaches the international level, it has turned into a different dispute from the domestic one. Often, the international dispute implies that at the local level the relationship between the foreign investor and the host State has gone through a gradual process of deterioration and ITA comes in as a measure of last resort.

When one looks at 'fork-in-the road' clauses, 'no-U-turn' clauses ${ }^{51}$ and the justification that ITA is needed because domestic courts are inadequate to settle the dispute, one is left with the impression that domestic courts and ITA are competing systems of adjudication. However, what the study shows is that in most cases investors chose to pursue domestic remedies first and only after the domestic avenues were unsatisfactory, did they initiate international arbitration. This suggests that instead of viewing domestic and international ISDS as competing systems of adjudication, we should view them as complementary. This different perspective

\footnotetext{
51 'No-U-turn' clauses forbid the investor to resort to domestic courts, once it has opted for ITA.
} 
can then help us conceptualize whether or not domestic courts should be included in one way or another in the international reform proposals (infra Part 4.3).

The need to broaden our perspective on what constitutes ISDS also allows us to understand that ISDS occurs on multiple levels, in various forms, before multiple fora. Domestic courts are already playing an important role in settling such disputes. Hundreds of thousands of locally incorporated companies with various degrees of foreign ownership operate around the globe, most of which most probably settle their disputes at the domestic level. However, we need to understand that not all domestic procedures involve domestic courts, just as not all international ISDS mechanisms are restricted to ITA. Recent IIAs illustrate this different way of thinking about ISDS. For example, the recent US-Mexico-Canada Agreement (USCMA, to replace NAFTA) provides for an exhaustion of local remedies clause for US-Mexico investment disputes. ${ }^{52}$ Furthermore, Articles 19 and 20 of the China-Hong Kong CEPA Investment Agreement (2017) do not provide for ITA. Instead, they include 'amicable consultation between the disputing parties', domestic administrative review, domestic court proceedings, and even resolution 'through the complaint handling organizations for foreign investors' in the PRC or Hong Kong. Thus, ISDS can take multiple forms, even domestic institutions purposely set up to handle disputes between foreign investors and the host State.

\subsection{We Need More Empirical Evidence on the Role of Domestic Courts}

In the Introduction, I mentioned how recent, predominantly empirical research has cast a shadow of doubt on some of the justifications for having ITA and investment treaties. As it turns out, there is no conclusive evidence that investment treaties promote investments and ITA does not seem to depoliticize disputes between investors and host States. ${ }^{53}$ My study questions the justification that ITA is needed because domestic courts are biased, inefficient or impartial.

During its $36^{\text {th }}$ Session in October-November 2018, Working Group III mentioned the importance of using facts during the deliberations and, where available and appropriate, to use statistical data. ${ }^{54}$ In other words, any reform proposals that affect policy should be based, as far as possible, on some form of objective data. Empirical projects ${ }^{55}$ have helped us better understand which legitimacy concerns affecting ITA are based on anecdotes and

\footnotetext{
52 Article 14.D.5 of the USCMA, text available at <https://ustr.gov/sites/default/files/files/agreements/ FTA/USMCA/Text/14_Investment.pdf>, accessed 23 July 2019. For a discussion of the role of domestic courts in the ISDS process in South Asia, see A. Saravan and S. Subramanian, "Role of Domestic Courts in the InvestorState Dispute Settlement Process: The Case of South Asian BITS", 20(2) International Arbitration Law Review (2017) 42.

53 Supra notes 9-10.

${ }^{54}$ UNCITRAL WGIII, 'Possible Reform of ISDS' (supra note 4), at 3/15.

55 Supra note 7. Also, see Thomas Schultz and Cédric Dupont, "Investment Arbitration: Promoting the Rule of Law or Over-Empowering Investors? A Quantitative Study", 25(4) EJIL (2015) 1147; Cédric Dupont, Thomas Schultz and Merih Angin, "Political Risk and Investment Arbitration: An Empirical Study", 7(1) JIDS (2016) 136; Alec Stone Sweet, Michael Yunsuck Chung and Adam Zaltzman, "Arbitral Lawmaking and State Power: An Empirical Analysis of Investor-State Arbitration”, 8(4) JIDS (2017) 579.
} 
misunderstandings, and which can be proven or disproven with the help of empirical data. However, as mentioned throughout this overview, this data-led approach should not be confined to ITA only, but should include other forms of ISDS. Whilst data is difficult to gather on commercial arbitration, domestic cases between foreign investors and host states are publicly more accessible.

The study should prompt researchers and the stakeholders involved in the reform process to consider non-ITA methods of ISDS as well, and to devise new empirical methods to assess some of the anecdotes and misconceptions surrounding domestic courts. Devising such methods is not an easy task. As mentioned, the study faced several limitations due to factors such as the language of the domestic proceedings, getting access to the domestic cases, and the difficulty to know who qualifies as a foreign investor in a seemingly endless sea of domestic proceedings, which makes assessing what happens in the bottom half of the 'ISDS iceberg' extremely challenging.

Furthermore, statistically testing domestic court bias, inefficiency and impartiality will probably not be sufficient. Machine learning could probably be employed, if one has access to machine-readable domestic databases containing information on the domestic subsidiaries of foreign companies. One would also need to employ more qualitative methods, such as interviews with relevant stakeholders in domestic proceedings, including the investors' counsel, the investors or local judges. There might be a discrepancy between the presence or absence of actual bias towards foreign investors, and the way foreign investors or their counsel perceive bias in domestic proceedings. This in turn can affect the choice of investors to pursue ITA, instead of domestic courts.

\subsection{Should Domestic Courts be Co-Opted as Investment Courts?}

Should domestic courts be co-opted as investment courts? If the term 'investment court' encompasses any type of standing judicial body that handles disputes between foreign investors and host States, then domestic courts can already be qualified as 'investment courts', , but at the domestic instead of the international level. Therefore, the question should be framed more as, should the reform proposals place greater emphasis on the role of domestic courts.

There are four options on the table, as discussed in the Introduction: (a) creating a standing, Multilateral Investment Court; (b) keeping the status quo, meaning ITA; (c) introducing an Appellate Body/Appeals Mechanism; or (d) resorting to domestic courts. Only the last option seems to consider resorting to domestic courts, and all options seem to follow the afore-mentioned understanding that international and domestic ISDS compete against one another. This is understandable, because historically ITA was meant to replace domestic courts for disputes between foreign investors and host States. However, as previously discussed, the 
complementary model better portrays the reality that a part of investors already uses domestic courts prior to ITA.

Consequently, if we are to follow the complementary model, then options (a), (b), and (c) could be improved by somehow requiring investors to resort to domestic courts first. For example, provided that the domestic proceedings are not excessively long, some disputes could be solved in a more efficient way domestically: shorter length of the proceedings and less costly litigation. Furthermore, investors have the possibility to appeal domestically - a limited possibility under option (b) - and domestic judges do not 'double hat' as some arbitrators do. ${ }^{56}$ Moreover, domestic proceedings offer more transparency, domestic courts can also have a better understanding of the facts of the dispute, and - provided they are sufficiently independent from the rest of the State apparatus - domestic courts might be able to provide a more legitimate balancing of important policy objectives with the rights of investors. ${ }^{57}$ Option (d) would completely take away the possibility of international ISDS, which is difficult to square with the complementary model. Under this model, there is no need to abolish international ISDS if it can coexist with domestic ISDS.

It must also be added that co-opting domestic courts also poses several challenges. Firstly, the most obvious challenge is that not all domestic judiciaries are impartial or independent. Secondly, in some countries domestic proceedings are excessively long. These two concerns can be circumvented (infra) if for example the exhaustion of local remedies clause includes a caveat that it does not apply when the domestic courts are unable or unwilling to hear the case. ${ }^{58}$ Thirdly, and more importantly, many domestic courts do not have experience with international law or investment treaties. However, as the data shows, the domestic cases analysed are initiated pursuant to domestic legislation and not pursuant to IIAs. As further explained (infra), in the cases analysed, investors also did not rely on IIAs in the domestic cases, and this is not due to the monist-dualist nature of the domestic system, but seems to be a result of the domestic dispute being different compared to the international one.

So if we are to follow the complementary model and combine domestic ISDS and international ISDS, why should we do so and how should we do it?

Concerning the question of why we should combine the two models, several points come to mind. The first one is factual: some foreign investors already use domestic ISDS mechanisms. As the study shows, in the four countries analysed more investors relied on domestic courts prior to ITA, than the ones that did not.

The second point is normative. One could argue that domestic courts in countries that follow the rule of law have higher normative legitimacy than ITA. They function in systems where there is a clear separation of powers, a hierarchy of norms with a constitution on top, a

\footnotetext{
${ }^{56}$ Langford, Behn, and Lie (supra note 7).

${ }^{57}$ For some further reflections see Leon E. Trakman, "Foreign Direct Investment: An Australian Perspective", 13 International Trade and Business Law Review (2010) 31, 52-3.

${ }^{58}$ This of course raises 'burden of proof' issues as well.
} 
hierarchy of courts, and a representative body(ies) tasked with the formation of new norms. Furthermore, they have plenary jurisdiction, well-established independence and authority, and strong enforcement powers. ${ }^{59}$ Contrast this to the normative legitimacy of investment tribunals existing in a normative system that is not fully developed; there is no clear hierarchy of norms and courts, the legal norms are often vaguely worded and there is no clear separation of powers. ${ }^{60}$ More so, the perceived legitimacy of ITA has suffered in recent years, if one considers the public protests against it. ${ }^{61}$ According to De Ly et al an exhaustion of local remedies clause 'could be a way to create and bring back some confidence to the BIT system. It would also strengthen the institutions and promote good governance in the host States [...]'. ${ }^{62}$

The third point is more pragmatic. Getting states to agree on a multilateral reform is not an easy task. States such as India favour including exhaustion of local remedy clauses into their recently concluded IIAs, ${ }^{63}$ while Brazil has been historically against investor-State arbitration. ${ }^{64}$ Thus, such states could more easily agree to create an international system that somehow includes domestic courts or other domestic means of ISDS.

How could we consolidate the complementary model? As is well known and thoroughly discussed, ${ }^{65}$ most IIAs do not require the exhaustion of local remedies and Article 26 of the ICSID Convention leaves it up to the Contracting States to require or not the exhaustion of local remedies as a condition of their consent to arbitrate under the Convention. My aim here is not to present the fine details of that discussion. Instead, we could get some guidance from the principle of complementarity found in the Rome Statue of the International Criminal Court (ICC). During the drafting of the Rome Statute, the concern arose of how to create an international court that did not excessively intrude into state sovereignty ${ }^{66}$ The drafters decided to give the ICC a complementary role in the enforcement of international crimes, the primary role reverting to domestic authorities.

Article 17 of the Rome Statue provides that the ICC is to admit a case if the national authorities are 'unwilling' or 'genuinely unable' to prosecute the person concerned. Whilst being aware of the dangers of transposing concepts from one field of law to another, one could

\footnotetext{
${ }^{59}$ Joshua Paine, "International Adjudication as a Global Public Good”, 29(4) EJIL (2019) 1223, 1248.

${ }^{60}$ See Philip Allots, “The Concept of International Law”, 10 EJIL (1999) 31.

${ }^{61}$ See Chris Johnston, "Berlin anti-TTIP Trade Deal Protest Attracts Hundreds of Thousands", The Guardian, 10 October $2015<$ https://www.theguardian.com/world/2015/oct/10/berlin-anti-ttip-trade-deal-rally-hundredsthousands-protesters $>$ accessed 23 July 2019.

${ }^{62}$ Filip De Ly, Bohuslav Klein, Nathalie Bernascone-Osterwalder, and Daniel M. Price, "Who Wins and Who Loses in Investment Arbitration - Are Investors and Host States on a Level Playing Field: The Lauder/Czech Republic Legacy", 6 JWIT (2005) 59, 70.

${ }^{63}$ Martin D. Brauch, "Exhaustion of Local Remedies in International Investment Law", IISD Best Practice Series, January $2017<$ https://www.iisd.org/sites/default/files/publications/best-practices-exhaustion-local-remedieslaw-investment-en.pdf $>$ accessed 23 July 2019, at 11.

${ }^{64}$ Leany Barreiro Lemos and Daniela Campello, "The Non-Ratification of Bilateral Investment Treaties in Brazil: A Story of Conflict in a Land of Cooperation", SSRN, 1 April 2013 https://papers.ssrn.com/sol3/papers.cfm?abstract_id=2243120 accessed 23 July 2019.

65 See Christophe Schreuer, "Interaction of International Tribunals and Domestic Courts in Investment Law" Contemporary Issues in International Arbitration and Mediation: The Fordham Paper 2010 (2011) 78.

${ }^{66}$ W.A. Schabas, The International Criminal Court: A Commentary on the Rome Statute (OUP, 2016$) 448$.
} 
think of a complementary mechanism to solve investor-State disputes. An international investment court, appellate body or arbitral tribunal would have a complementary role in solving the dispute between the investor and the host State. This could alleviate further state fears over the loss of sovereignty as domestic ISDS mechanisms would be the first ones to hear the dispute. One could even think of creating some local institutions specialized on solving disputes between foreign states and host States, inspired by the China-Hong Kong investment agreement. However, to ensure that investors also have access to international ISDS, they could bring an international claim if they can prove that the domestic institutions are unwilling or unable to solve their dispute.

It must also be mentioned that in order for such a complementary model to function, a wider definition of 'dispute' would be needed. As mentioned, the FITR clause often does not function in practice because investor-State tribunals have a very narrow understanding of the 'dispute' being the same at the international and domestic levels, requiring that between the international and the domestic cases there be an identity of the parties, the facts, and the legal rules being invoked. However, such stringent conditions would make an exhaustion of local remedies (ELR) clause inoperable in practice. Therefore, what should matter is that the same government measures form the basis of the domestic and later on the international claim. A strict identity of the parties is not needed, as the domestic cases are often brought by domestically incorporated companies, which are different legal entities from the foreign investors.

Furthermore, concerning the legal norms being invoked, no identity would be required as in an ITA case the applicable law will mainly be formed by the underlying IIA, whilst in domestic cases investors will mostly rely on domestic laws to substantiate their claim and not the standards included in IIAs. As an illustration, I looked at the rules invoked in all the domestic cases - to which I had full access - to see whether or not investor's might have invoked IIAs besides domestic law. I only found two domestic cases that referred to IIAs or their implementing legislation (and this was not dependent on the country being monist or dualist). In Tembec Inc $v$ US, ${ }^{67}$ which preceded the UNCITRAL arbitration in Domtar $v$ US (tribunal not constituted), the US Court of International Trade referred to the determination of an Article 1904 NAFTA Panel in an anti-dumping case. However, this case did not concern the usage of the NAFTA provisions pertaining to investment protection as a basis for the claim.

The second case was AVAS v SC C.M.E.I.E. SRL, referenced in Roussalis v Romania. ${ }^{68}$ However, in this case as well the provisions of the IIA were not used to argue the merits of the case. Instead, the State agency (AVAS) argued that the Romanian tribunal lacked jurisdiction, because a BIT existed that provided for its own mechanism to solve investor-state disputes. The Bucharest Court of Appeals rejected this argument. It referred to Law 166/1997 implementing the Romania-Greece BIT which provided for international arbitration and the usage of local courts. The Court of Appeals concluded that it had jurisdiction to hear the case as the dispute was contractual, not treaty based, and the company involved was a Romanian company,

\footnotetext{
67441 F. Supp. 2d 1302.

${ }^{68}$ Roussalis $v$ Romania, ICSID ARB/06/01.
} 
registered in the country. ${ }^{69}$ Subsequently, the Supreme Court of Romania also dismissed the State agency's arguments regarding the Court's lack of jurisdiction. It held that the company in question was a Romanian entity, therefore, the law implementing the BIT was not applicable to the dispute. ${ }^{70}$

\section{Conclusions}

This overview illustrates that there is a gap in our knowledge of how domestic courts handle investor-state disputes. As it turns out, a part of foreign investors uses the domestic courts of the host State prior to initiating investment treaty arbitration. Subject matter-wise these cases are very diverse, and not all of them are initiated by investors against the host State. Moreover, in the four countries analysed, investors often appealed to the highest courts of the land, but they lost more cases than they won. These findings can help UNCITRAL Working Group III conceptualize the meaning of 'investor-state dispute' and the interplay between domestic and international methods of ISDS. Further empirical research is needed to understand how domestic courts handle investor-state disputes. This in turn can help us develop normative arguments as to why domestic courts should or should not be included in the reform process.

\footnotetext{
${ }^{69}$ AVAS v SC C.M.E.I.E. SRL, Bucharest Court of Appeals, Commercial Section VI, Decision 430 of 08.10.2007, File No: 7341/3/2003.

${ }^{70}$ AVAS v SC C.M.E.I.E. SRL, Romanian Supreme Court, Decision 2090/2009 of 30.03.2009.
} 